\title{
KURIKULUM INTRA DAN EKSTRA KURIKULER PADA MAN I SAMARINDA DAN RELEVANSINYA DENGAN PERKEMBANGAN MUATAN LOKAL
}

\author{
Oleh: Rosdiana. ${ }^{\prime} *$ '
}

Abstract
Research aims to describe and identify the local content elements in
curriculum applied in MAN I Samarinda, and related community re-
sponse. From the findings, it shows that Madrasah Aliyah Negeri 1
Samarinda has implemented in its learning process the program of
skill development on dressmaking, welding, automotive, and com-
puter techniques and integrated it with local content elements. Many
parties have had good responses saying that the school as religious
based instruction institution has breasted the times as it has been
capable to combine the religious knowledge, skill and science. Their
positive response comes as they believe that the skill development
program could prepare the student to be able to go in labour market
competition.

Key Word: curriculum, relevance, local development

\section{PENDAHULUAN}

T embaga pendidikan agama dan keagamaan seperti dalam UndangUndang Nomor 20 Tahun 2003 Tentang Sisdiknas dan Peraturan Pemerintah Nomor 55 Tahun 2007 tentang Pendidikan Agama dan Pendidikan Keagamaan semakin menguat, karena di samping penguatan tersebut bukan hanya legalitas eksistensi kelembagaan, juga penyelenggaraan dan tanggung jawab akademis, sehingga ketentuan-ketentuan pengelolaan lembaga pendidikan umum dan atau kejuruan jenjang dasar dan menengah juga berlaku

Penulis adalah Peneliti Balai Penelitian dan Pengembangan Agama Makassar. 
pada madasarah dan pesantren. Salah satu ketentuan strategis dalam penyelenggaraannya adalah kurikulum. ${ }^{2}$

Kurikulum, yang tidak sedikit memberi kontribusi dalam pembelajaran di lembaga-lembaga pendidikan formal, dilakukan silih berganti. menjadi semacam barometer tersendiri terhadap berhasil tidaknya proses pengajaran pada lembaga pendidikan formal, ${ }^{3}$ (termasuk pada lembaga pendidikan agama dan pendidikan keagamaan yang dibina oleh Departemen AgamaMaka dikenallah beberapa kurikulum, dorongan untuk mengkreasi kurikulum pada satuan-satuan pendidikan semakin menguat dengan diterapkannya kurikulum KTSP sejak tahun 2006, yang memberi kewenangan pada satuan-satuan pendidikan untuk menyusunnya sekaligus melaksanakan dan mengevaluasinya. Salah satu aspek dalam kurikulum yang akan ditelusuri melalui penelitian ini adalah muatan lokal dalam struktur kurikulum.

Kekurangoptimalan muatan unsur-unsur lokal dalam kurikulum lembaga pendidikan agama dan pendidikan keagamaan perlu ditelusuri melalui kajian penelitian. Kajian penelitian ketermuatan unsur-unsur lokal dalam kurikulum penting dilakukan oleh karena selain memberikan kontribusi bagi penguatan lembaga pendidikan agama dan keagamaan dalam pengembangan kurikulum, juga untuk mendekatkannya dengan masyarakat.

Penelitian ini dilakukan di Kota Samarinda. Sasaran penelitian adalah MAN I Samarinda, penentuannya dilakukan secara purposive dengan teknik-teknik sebagai berikut: Sampel individu, juga dipilih secara purposive, yakni: Para pengelola/komunitas madrasah terpilih, pejabat terkait dalam jajaran Departemen Agama, dan tokoh masyarakat dari berbagai unsur. Untuk menjaring data yang diperlukan dalam penelitian, teknik yang akan dilakukan, yaitu: wawancara, studi dokumentasi, dan studi pustaka. Pengolahan data dilakukan dengan memperhatikan bentuk dan sifat data yang terkumpul. Data yang dihimpun lebih bersifat data kualitatif, sehingga pengolahannya lebih bersifat kategorisasi. Sedangkan analisis data lebih bersifat analisis deskriptif dan naratif serta diberikan interpretasi yang relevan dengan masalah dan tujuan penelitian. ${ }^{4}$

\section{TINJAUAN PUSTAKA}

\section{Pengertian Kurikulum}

Secara etimologis, kurikulum (curriculum) berasal dari bahasa Perancis (courier=berlari), awalnya mempunyai pengertian a running course (sebuah acuan mata pelajaran) yang harus ditempuh untuk mencapai suatu gelar penghargaan dalam dunia pendidikan yang dikenal dengan ijazah. ${ }^{5}$ 
Secara terminologis, kurikulum dimaknai sebagai curriculum is interpreted to mean all of the organized course, activities, and experiences wich pupils have under direction of the school, whether in the class room or not (Kurikulum diinterpretasikan sebagai alat pengorganisasi semua mata pelajaran, aktivitas-aktivitas dan pengalaman-pengalaman siswa di bawah tanggung jawab sekolah, adakalahnya di dalam kelas atau di luar kelas".6

Pada Undang-Undang Nomor 20 Tahun 2003 tentang Sistem Pendidikan Nasional pada Bab I pasal 1 ayat 9 menetapkan bahwa "kurikulum adalah seperangkat rencana dan pengaturan mengenai tujuan, isi, dan bahan pelajaran serta cara yang digunakan sebagai pedoman penyelenggaraan kegiatan pembelajaran untuk mencapai tujuan pendidikan tertentu. ' Pengembangannya (pasal 36 ayat 2) pada semua jenjang dan jenis pendidikan dikembangkan dengan prinsip diversifikasi sesuai dengan satuan pendidikan, potensi daerah, dan peserta didik. Kemudian (pasal 37 ayat 1) menetapkan muatan kurikulum, meliputi: pendidikan agama, pendidikan kewarganegaraan, bahasa, matematika, IPA, IPS, seni dan budaya, pendidikan jasmani dan olahraga, keterampilan/kejuruan, dan muatan lokal.

Sebagai pengembangan dari Undang-Undang Sisdiknas di atas, maka pada Peraturan Pemerintah Nomor 19 Tahun 2005 tentang Standar Nasional Pendidikan yang menjadi kerangka dasar penyusunan kurikulum, tingkat satuan pendidikan dan silabusnya pada setiap satuan pendidikan, pada Bab I pasal 1 ayat 15 menyebutkan bahwa kurikulum tingkat satuan pendidikan adalah kurikulum operasional yang disusun dan dilaksanakan oleh masing-masing satuan pendidikan. ${ }^{8}$

\section{Struktur Kurikulum}

Pengembangan kerangka dasar kurikulum ke dalam struktur kurikulum, melalui Kepmendiknas Nomor 22 Tahun 2006 tentang Standar Isi. Struktur kurikulum pendidikan menengah terdiri atas 3 komponen muata kurikulum, yaitu:

a. Komponen mata pelajaran, berisi struktur kurikulum tingkat sekolah, yang disusun berdasarkan kebutuhan siswa dan sekolah terkait dengan upaya pencapaian standar kompetensi lulusan (SKL).

b. Komponen muatan lokal; berisi tentang jenis, strategi pemilihan, dan pelaksanaannya yang diselenggarakan oleh sekolah.

c. Komponen pengembangan diri; diberikan kepada peserta didik untuk dan mengekspresikan diri sesuai dengan kebutuhan, kemampuan, bakat, minat peserta didik, dan kondisi sekolah.' 


\section{Muatan Lokal dalam Kurikulum}

Pemberlakuan kurikulum tingkat satuan pendidikan (KTSP) pada masingmasing jalur dan jenjang satuan pendidikan, pengakomodiran karakteristik lingkungan daerah, dalam kurikulum pembelajaran di sekolah dapat dilakukan, oleh karena dalam struktur kurikulum KTSP, terdapat salah satu komponen, yaitu komponen muatan lokal.

Muatan lokal adalah program pendidikan yang isi dan media penyampaiannya dikaitkan dengan lingkungan alam, lingkungan sosial, lingkungan budaya, serta kebutuhan daerah dan wajib dipelajari oleh peserta didik di daerah itu.

\section{HASIL DAN PEMBAHASAN}

\section{Kondisi Pendidikan Keagamaan di Kota Samarinda}

Upaya peningkatan mutu pendidikan terus menjadi agenda penting bagi pemerintaha kota Samarinda khususnya, yang dimaksudkan untuk menghasilkan manusia yang seutuhnya lahir dan batin. Sedangkan peluasan kesempatan belajar dimaksudkan agar penduduk usia sekolah yang setiap tahun mengalami peningkatan sejalan dengan laju pertumbuhan penduduk untuk dapat memperoleh kesempatan pendidikan yang seluas-luasnya, baik pendidikan umum maupun pendidikan agama. Pelaksanaan pembangunan pendidikan di Kota Samarinda selama ini mengalami peningkatan dari tahun ke tahun. Indikator yang dapat mengukur tingkat perkembangan pendidikan di Kota Samarinda seperti jumlah dan jenis sekolah, jumlah guru dan murid.

Ketersedian sarana pendidikan di Kota Samarinda untuk Madrasah Ibtidaiyah, Tsanawiyah, dan Aliyah lihat tabel 1.

\begin{tabular}{|c|c|c|c|c|}
\hline $\mathrm{NO}$ & MADRASAH & KETERANGAN & JUMLAH & Total \\
\hline 1 & RA & - & 6 & 6 \\
\hline \multirow{2}{*}{2} & \multirow{2}{*}{ Ibtidaiyah } & Negeri & 2 & \multirow{2}{*}{18} \\
\hline & & Swasta & 16 & \\
\hline \multirow{2}{*}{3} & \multirow{2}{*}{ Tsanawiyah } & Negeri & 1 & \multirow{2}{*}{29} \\
\hline & & Swasta & 28 & \\
\hline \multirow{2}{*}{4} & \multirow{2}{*}{ Aliayah } & Negeri & 2 & \multirow{2}{*}{12} \\
\hline & & Swasta & 10 & \\
\hline
\end{tabular}

Sementara jumlah pemeluk agama yang berada di kota Samiranda adalah Islam 588.124 orang, Katolik 32.048, Protestan 38.745, Hindu 10.076, Budha 9.355 sementara ketersediaan rumah ibadah sebagai sarana dan prasana 
pendukung dalam beribadah di kota Samarinda yaitu: 274 masjid, 495 langgar, 63 mushallah, 10 gereja Katolik, 60 gereja Protestan, 5 Pura, dan 8 Vihara.

\section{Deskripsi MAN I Samarinda}

MAN I Samarinda pada awalnya didirikan pada tanggal 19 Juli 1978 berdasarkan keputusan Menteri Agama Nomor 150.517.150, yang merupakan perubahan Sekolah Persiapan IAIN (SPIAIN) dan cabang dari IAIN Sunan Ampel yang berlokasi di Kampus IAIN Jin. Abul Hasan Kelurahan Pasar Pagi. Pada awalnya MAN I Samarinda hanya memiliki jurusan Agama dan pada tahun 1982/1983 menambah dua jurusan yaitu jurusan IPAdan IPS.

Akibat perkembangan jumlah peminat yang ingin memuntut ilmu di MAN Samarinda, mendesak pihak terkait untuk melebarkan sayapnya dengan berhasil membebaskan tanah seluas 1,56 hektar pada tahun 1984 di jln. P. Suryanata Kelurahan Air Putih Kecamatan Samarinda Ulu yang ditempati hingga sekarang. Pembangunan gedung terus dilakukan dan ditempati pada tahun 1984/1986, dan pada tahun 1988 telah dibangun ruang perpustakaan dan laboratorium IPA, yang dimaksudkan untuk melengkapi fasilitas pembelajaran yang ada. Nama MAN (Madrasah Aliyah Negeri) berubah menjadi MAN I Samarinda setelah alih fungsi MAN menjadi MAN I tahun 1990, dikarenakan keberadaannya yang lebih dahulu maka ditetapkan secara kesepahaman menjadi MAN I Samarinda.

Keadaan guru MAN I Samarinda dewasa ini memiliki tenaga pengajar 50 orang pegawai sebanyak 8 orang, dengan rincian sebagai berikut: guru PNS sebanyak 27 orang (13 orang laki-laki dan 14 orang perempuan), Guru Tidak Tetap 23 orang (11 orang laki-laki dan 12 orang perempuan), pegawai PNS sebanyak 4 orang dan PTT sebanyak 4 orang. Total keseluruhan guru (PNS dan GTT) dan pegawai (PNS dan PTT) sebanyak 58 orang.

Keadaan siswa MAN I Samarinda untuk tahun ajaran 2008/2009 secara keseluruhan adalah 443 orang terdiri atas : kelas $\mathrm{X}=137$ orang, kelas $\mathrm{XI}=135$ orang, dan kelas XII $=171$ orang.

Prestasi MAN I Samarinda cukup membanggakan ini terbukti dari berbagai prestasi yang diraih baik tingkat lokal maupun tingkat nasional. Berbagai prestasi dibidang olah raga seperti (bulu tangkis, tenis meja, volley ball, senam, gerak jalan, dan baris berbaris), lomba pidato bahasa Arab dan bahasa Inggris, MTQ, Kaligrafi kontemporer, puisi Islam dan teater. Kategori prestasi yang diraih mulai peringkat terendah harapan II hingga prestasi tertinggi yaitu juara I telah di kantongi oleh siswa siswi MAN I Samarinda. 
MAN I Samarinda menempati areal seluas $15.065 \mathrm{~m}^{2}$ yang terdiri atas penggunaan tanah untuk bangunan/gedung seluas 9,697 $\mathrm{m}^{2}$, untuk sarana lingkungan $5,368 \mathrm{~m}^{2}$. Sarana dan prasaran yang menunjang proses pembelajaran pada MAN I Samarainda cukup memadai dengan tersedianya fasilitas, ruang belajar, perpustakaan, laboratorium (komputer, bahasa, IPA, Mushallah, sarana olah raga, koperasi, ruangan workshop (tata busana, las, dan otomotif), dan sarana lainnya yaitu: ruang kepala madrasah, wakil kepala madrasah, TU, guru, $\mathrm{BP}$, security, pertemuan, aula, dapur, WC, kantin, lapangan dan parkir.

\section{Monografi Muatan Lokal di MAN I Samarinda}

Selaras dengan tujuan pendidikan adalah mengantarkan peserta didik menjadi manusia dewasa, yakni manusia yang mampu berfikir dan bertindak atas pilihan dan inisiatifnya sendiri. Dalam makna seperti ini ukuran benar tidaknya arah pendidikan adalah dengan menguji apakah praktek pendidikan dan pengajaran di madrasah/sekolah membantu anak didik semakin dewasa dan otonom, atau membuat anak didik terus tergantung pada otoritas dan tidak mandiri.

Berdasarkan hal tersebut kurikulum ditetapkan untuk mengakomodasi berbagai kebutuhan-kebutuhan yang terkait berbagai aspek dimaksud. MAN I Samarinda memiliki struktur kurikulum berdasarkan standar isi yaitu mata pelajaran kurikuler, pengembangan diri, dan muatan lokal. Keterkaitan mata pelajaran inti, pengembangan diri, dan muatan lokal dalam mengakomodir unsur-unsur lokal dalam kurikulum terkait potensi, kebutuhan dan kecenderungan masyarakat kota Samarinda, oleh MAN I Samarinda berupaya dan berusaha untuk mencover kebutuhan-kebutuhan tersebut dengan menetapkannya dalam sistem pembelajaran dengan mengintegrasikannya ke dalam proses pembelajaran.

\section{Mata Pelajaran Intar Kurikuler}

Kerangka dasar dan struktur kurikulum muatan mata pelajaran yang diberikan di MAN I Samarinda disesuaikan dengan struktur kurikulum yang terdapat dalam standar isi yang telah ditetapkan oleh Kepmendiknas nomor 22 tahun 2006 yang didalamnya termuat kerangka dasar dan kurikulum, beban belajar, kurikulum tingkat satuan pendidikan, dan kalender pendidikan sehingga nama kurikulumnya adalah "Kurikulum Mandarash Aliyah Negeri I Samarinda". Struktur kurikulum madrasah meliputi substansi pembelajaran yang ditempuh dalam satu jenjang pendidikan selama tiga tahun mulai dari kelas X sampai XII, susunannya berdasarkan standar Kompetensi Lulusan (SKL), Standar Kompetensi, dan Kompetensi Dasar. 
Pengorganisasian kelas-kelas pada MAN I Samarinda dibagi ke dalam dua kelompok, yaitu kelas X merupakan program umum yang diikuti oleh seluruh peserta, kelas XI dan XII merupakan program penjuruan yang terdiri atas dua program yaitu program Ilmu Pengetahuan Alam dan program Ilmu Pengetahuan Sosial, dua program tersebut sama dengan program Sekolah Menengah Umum dalam hal mata pelajaran kurikuler, tetapi untuk kelas X dan XI ditambah dengan Mata Pelajaran Program Keterampilan. Alokasi waktu satu jam pembelajaran adalah 45 menit serta minggu efektif dalam satu tahun pembelajaran (dua semester) antara 34-38 minggu.

Mata pelajaran program keterampilan yang ditetapkan pada MAN I Samarinda sebagai program pilihan yang diikuti oleh semua siswa, program keterampilan ini terdiri atas program keterampilan tata busana, program keterampilan las, dan program ketarampilan otomotif. MAN I Samarinda sejak tahun 1999/2000 ditunjuk oleh kanwil Depag sebagai madrasah dengan program ketarampilan. Program keterampilan ini dikembangkan berdasarkan kepentingan dan kebutuhan daerah yang didasarkan akan keputusan dan musyawarah bersama internal Madrasah Aliyah Negeri I Samarinda sebelum ditetapkan dan setujui oleh kanwil Depag Kaltim pada tahun 1999/2000. Program kerampilan ini di tetapkan dan di peruntuk bagi pengembangkan kompetensi yang disesuaikan dengan unsur-unsur lokal, ciri khas dan potensi lokal daerah Samarinda, termasuk keunggulan daerah Samarinda, yang materinya dikelompokkan ke dalam mata pelajaran yang ada. Substansi mata pelajaran program keterampilan ditentukan oleh satuan pendidikan.

Kurikulum keterampilan tata busana, las, dan otomotif disusun untuk mencapai tujuan pendidikan Madrasah Aliyah, khususnya tujuan program pendidikan keterampilan. Kurikulum ini merupakan seperangkat rencana dan pengaturan mengenai isi dan pelajaran serta cara yang digunakan sebagai pedoman penyelenggaraan kegiatan belajar di Madrasah Aliyah. Program keterampilan pada MAN I Samarinda terdiri dari program pokok yang diselenggarakan pada kelas X dan kelas XI. Program ketrampilan ini diberikan pada semua tingkatan dan jurusan, baik jurusan IPA maupun IPS dan untuk kelas XII masing-masing program keterampilan ini dikurangi mengingat konsentrasi siswa pada Ujian Sekolah (US) maupun Ujian Nasional (UN).

Selain mata pelajaran program keterampilan tata busana, otomotif, dan las, beberapa mata pelajaran intra/inti yang dalam proses pembelajarannya berusaha untuk melestarikan dan membudayakan unsur-unsur lokal kota Samarinda yaitu 
mata pelajaran Seni Budaya. Mata pelajaran seni budaya yang mempunyai kompetensi dasar: memahami budaya rupa Nusantara, indikator pembelajaran mendeskripsikan karya seni rupa terapan di wilayah nusantara sesuai dengan kehidupan sosial budaya kota Samarinda khususnya dan Kaltim umumnya. Kompetensi dasar membuat karya seni rupa ciri khas setempat, seni kaligrafi, dan menggambar ragam hias khas Kalimantan.

Mata Pelajaran TIK pada MAN I Samarinda di samping memiliki kompetensi dasar sesuai dengan kurikulum yang ada juga mengembangkan materi TIK tambahan, bertujuan untuk memberikan wawasan dan keterampilan penggunaan IT, siswa dipersiapkan memiliki kemampuan skill yang utuh terhadap penguasaan teknologi informasi dan komunikasi sesuai kebutuhan peserta didik dan tuntutan masyarakat lokal khsusnya. Mata Pelajaran TIK pada awalnya merupakan muatan lokal yang dikembangkan untuk menyonsong tantangan informasi yang global. Materi tambahan mata pelajaran TIK meliputi:

\begin{tabular}{|c|c|c|}
\hline $\mathrm{NO}$ & KELAS & Program Tambahan \\
\hline 1 & $\mathrm{X}$ & $\begin{array}{l}\text { 1.Internet } \\
\text { 2. Visual basic } \\
\text { 3. Pascall }\end{array}$ \\
\hline 2 & XIIPA & $\begin{array}{l}\text { 1. Adobe Photoshop } \\
\text { 2. Corel Draw } \\
\text { 3. M acromedi a FI ash }\end{array}$ \\
\hline 3 & XI IPS & $\begin{array}{l}\text { 1. Aeon ting System } \\
\text { 2. Program Aplikasi akuntansi }\end{array}$ \\
\hline 4 & XIIIPA & $\begin{array}{l}\text { 1. Web-design } \\
\text { 2. LAN } \\
\text { 3. Merakit Hardware } \\
\text { 4. Maintenance Komputer }\end{array}$ \\
\hline 5 & XII IPS & $\begin{array}{l}\text { 1. Web Accounting system } \\
\text { 2. merakit Hardware } \\
\text { 3.Maintenance computer }\end{array}$ \\
\hline
\end{tabular}

Program ketampilan yang ditetapkan pada MAN I Samarinda merupakan kegiatan kurikuler untuk mengembangkan kompetensi yang disesuaikan dengan ciri khas dan potensi daerah, termasuk keunggulan daerah. Materinya tidak dapat dikelompokkan ke dalam mata pelajaran yang ada. Substansi muatan lokal ditentukan oleh satuan pendidikan. Mata pelajaran muatan lokal berkaitan dengan pemberlakuan otonomi daerah, suatu peralihan dari sentralisasi ke desentralisasi pemerintahan dan pendidikan. Tujuan pembelajaran muatan lokal memberikan bekal pengetahuan, keterampilan, dan perilaku kepada peserta didik agar mereka memiliki wawasan yang integralistik. 
siswa-siswinya untuk hal tersebut. Antisipasi regenerasi dari khusus kelompok tahlilan ini terns dilakukan dengan pembinaan dan bimbingan. Kelompok tahlilalan MAN I Samarinda terdiri lebih kurang 20 orang.

\section{Respon Masyarakat Terhadap Muatan Lokal di MAN I Samarinda}

Kebijakan otonomi daerah dan desentralisasi dalambidang pendidikan yang bertujuan untuk memberi peluang kepada peserta didik untuk memperoleh keterampilan, pengetahuan, dan sikap yang dapat memberikan kontribusi kepada masyarakat, tidak mengagetkan para pengelola madrasah. Madrasah juga lebih survive terhadap perubahan kurikulum tersebut. Manajemen desentralisasi tersebut memberikan kewenangan kepada madrasah/sekolah untuk melaksanakan PBM sesuai dengan kebutuhan yang dikondisikan untuk kebutuhan lokal. Dengan demikian, maka madrasah mendapatkan angin segar untuk bisa lebih eksis dalam mengatur kegiatannya tanpa intervensi pemerintah pusat dalam upaya mencapai peningkatan mutu pendidikannya. Melalui proses belajar mengajar yang didasari dengan kebutuhan lokal, efektivitas proses belajar mengajar diharapkan bisa tercapai sehingga menghasilkan prestasi belajar yang lebih tinggi.

Sejalan dengan hal tersebut diungkapkan oleh Dra. Hj Mudi"ah, M.Pd: Kurikulum ini tentunya dikembangkan berdasarkan kebutuhan dan kondisi lokal kami kota Samarinda, sama halnya pemilihan program keterampilan yang kami kembangkan yaitu program las, otomotif dan tata busana serta sebelumnya kami telah memiliki program keterampilan komputer. Muatan lokal diupayakan relevan dengan kebutuhan lingkungan yang sekaligus menjadi potensi bagi setiap peserta didik dalam pengembangan keterampilan individu, di samping keterampilan akademik, sehingga siswa memiliki modal dasar setelah tamat untuk melanjutkan pendidikan atau setidaknya memiliki keterampilan dasar dalam memasuki dunia usaha jika mereka tidak dapat melajutkan pendidikan ke perguruan tinggi. Dalam penyusunan kurikulum partisipasi masyarakat khususnya orang tua dilakukan dalam wadah Komite Madrasah yang setiap tahun ajaran terlibatkan dalam menyusun KTSP serta membahas berbagai aspek terkait perkembangan dan masalah-masalah yang dihadapi oleh madrasah.

Urgensi muatan lokal yang ditetap Madrasah atau satuan pendidikan tertentu diungkapkan oleh Dra Hj. Itji Rukiah, sangat mengapresiasi dengan pemilihan muatan lokal yang ada, karena hal tersebut sangat relevan dan berhubungan dengan kondisi masyarakat kota Samarinda yang heterogen. Hendaknya dalam penerapan dan penentuan muatan lokal, satuan pendidikan hams mempertimbangkannya muatan lokal yang harus di terapkan, kaitannya dengan kondisi yang ada di daerah, 


\section{Rosdiana}

seperti kondisi lingkungan satuan pendidikan, lingkungan alam, lingkungan sosial, lingkungan budaya, dan kebutuhan masyarakat lokal. Terlebih kepentingan bagi siswa itu sendiri, supaya siswa-siswa setelah tamat memperoleh sesuatu, dan muatan lokal tersebut hendaknya menjembatani siswa untuk dapat mengenali daerahnya, keunggullan dan kebutuhannya daerah tersebut.

Keterlibatan berbagai pihak dalam pendidikan menyebabkan para pengelola madrasah memfokuskan pada program-program yang berkaitan dengan kondisi lokal kota Samarinda sebagai sarana meningkatkan kualitas pendidikan. Program-program keterampilan MAN I Samarinda di pilih sebagai salah satu upaya untuk memberikan keterampilan dasar bagi siswa.

Secara teknis urgensi pogram keterampilan yang berbasis masyarakat luas adalah keterampilan atau upaya-upaya kreatif dan inovatif dengan jalan mengembangkan ide dan sumber daya untuk memenuhi kebutuhan hidupnya, bukan semata-mata berorientasi kepada jalur akademik, akan tetapi dewasa ini madrasah dituntut agar mampu mewujudkan pertautan yang jelas dengan dunia kerja. Paradigma bersekolah untuk bekerja (school to work) harus mendasari semua kegiatan pendidikan. Menurut H. Mahmudi, BA: Dalam mengantisipasi persaingan global, perlu disiapkan lulusan peserta didik yang memiliki pengetahuan dan keterampilan yang berkualitas serta sikap teladan, dalam rangka ikut berpartisipasi dalam persaingan dunia kerja. Memasuki milenium ke tiga dan persiapan global yang lebih beretika sangat mendesak dunia pendidikan membuat program yang berorientasi pada dunia kerja tersebut. Dari siswa lulusan MAN I Samarinda sudah banyak yang terjun kedunia kerja baik yang bekerja secara mandiri melalui home industry atau usaha micro kecil maupun masuk ke perusahan-perusahan (dunia industri).

Program keterampilan yang diperoleh di MAN I Samarinda melalui teori dan praktek, merupakan suatu disiplin ilmu yang perlu dipelajari. Kemampuan seseorang dapat dimatangkan melalui proses pendidikan. Keterampilan juga merupakan disiplin ilmu yang memiliki objek tersendiri, yaitu kemampuan untuk menciptakan sesuatu yang baru dan berbeda. keterampilan yang dimaksudkan adalah keterampilan yang berbasis potensi daerah, yang tujuannya adalah untuk meningkatkan kemampuan siswa untuk mengenal dan mengembangkan potensi daerahnya tersebut.

Berdasarkan filosofi pendidikan negara mencerdaskan bangsa dan meningkatkan kualitas manusia Indonesia serta kebutuhan disiplin ilmu yang berkaitan dengan berbagai keterampilan dalam sebuah kurikulum pendidikan menunjukkan pentingnya pemberian mata pelajaran keterampilan dikalangan siswa. Memiliki keterampilan perlu dimaksimalkan, sehingga dalam suatu penerapan program keterampilan dalam mata pelajaran muatan lokal yang berbasis potensi 

lokal memiliki tujuan di samping untuk memupuk potensi dalamjiwa siswa tersebut juga untuk menyiapkan lulusan yang termasuk dalam usia produktif dengan jiwa mengembangkan potensi lokal daerah mereka dan memiliki kesadaran tinggi dalam mengaktualisasikan potensinya secara cerdas dan mandiri.

Selain program keterampilan las, otomotif dan tata busana yang di tetapkan oleh pihak MAN I Samarinda dalam rangka pengembangan nilai tambah bagi siswa yang akan memiliki keahlian tersendiri, juga mengembangkan kegiatankegiatan lain dalam bentuk kegiatan ekstrakurikuler, seperti program muhadharah yang bertujuan untuk mendidik dai-daiyah, BBAQ, dan lain-lain. kegiatan-kegiatan ini merupakan salah satu bentuk untuk menyeimbangkan antara mata pelajaran inta kurikuler, kegiatan ekstrakurikuler dan program keterampilan yang ada pada MAN I Samarinda.

Selaras dengan hal tersebut KH. Fachruddin Wahab berpendapat: bahwa setiap mata pelajaran baik mata pelajaran inti maupun mata pelajaran lain, seharusnya memperhatikan materi yang diajar dan perlu untuk mengkaitkannya pada unsur-unsur lokal yang ada di kota Samarinda serta wajib menyeimbangkannya dengan nilai-nilai Islam.

Mata pelajaran agama adalah salah satu kelompok mata pelajaran yang wajib diberikan. Kelompok mata pelajaran agama dan akhlak mulia dimaksudkan untuk membentuk peserta didik menjadi manusia yang beriman dan bertakwa kepada Tuhan Yang Maha Esa serta berakhlak mulia. Aktualisasi dari pembelajaran ini dikembangakan dalam kegiatan-kegiatan ekstrakurikuler.

Akhlak mulia mencakup etika, budi pekerti, atau moral sebagai perwujudan dari pendidikan agama. Dengan melihat tujuan pembelajaran agama tersebut, tampak jelaslah bagaimana seharusnya pembelajaran agama ini berperan. Memang tugas membentuk peserta didik tersebut bukan ssj<adar tanggung jawab guru agama di sekolah, melainkan seluruh guru memiliki peran yang sama pentingnya. Namun demikian, melalui pembelajaran agamalah yang lebih dekat dan mempunyai peran yang strategis. Alumni Madrasah, bagaimanapun nilai raport dan hasil ujiannya, moral keagamaan yang melekat pada sikap dan perilakunya akan menjadi tolok ukur bagi keberhasilan lembaga pendidikan yang menjadi tempat ia belajar.

Salah satu bentuk yang perlu mendapat perhatian adalah SDM pengelola dari Madrasah meliputi tenaga pendidik yang kompeten terhadap bidang studi yang diajarkan, hal tersebut dalam rangka peningkatan mutu pendidikan yang diharapkan. Menurut Drs. Edi Purwandono, M.Pd: Program keterampilan yang ditawarkan MAN I Samarinda adalah merupakan program untuk memberikan 
life skill bagi siswa-siswi. Kererampilan ini diharapkan dapat menjadi bekal dan modal dasar bagi siswa untuk terjun kemasyarakat bila ia telah menamatkan pendidikan, khususnya bagi siswa yang tidak melanjutkan pendidikan keperguruan tinggi. Program-program keterampilan ini hendaknya betul-betul memperhatikan berbagai aspek yang terkait pada proses pembelajarannya seperti ketersediaan tenaga yang ahli di bidangnya, fasilitas, sarana dan prasarana yang memadai dan hal ini merupakan tuntutan yang harus menjadi perhatian berbagai pihak. Sejauh ini partisipasi masyarakat khususnya orang tua siswa cukup baik terlihat dari tawaran untuk memberikan bimbingan keterampilan kepada siswa.

\section{Relevansi Pengembangan Muatan Lokal di MAN I Samarinda}

Penerapan mulok di madarasah khususnya di kota Samarinda, dalam aspek kebutuhan dan keadaan daerah serta mencoba mengajukan berbagai alternatif pemecahan masalah yang dihadapi dalam penerapan mulok tersebut. Hasilnya diharapkan menjadi bahan saling tukar informasi dan diskusi bagi upaya pengembangan kurikulum muatan lokal, utamanya yang berkaitan dengan aspek kondisi kota Samarinda khususnya dan Kalimantan Timur umumnya.

Berbagai kebijakan bahwa isi mulok pada masing-masing daerah dapat berupa mata pelajaran kesenian, keterampilan (bercocok tanam, pertukangan, mengukir, mengayam, membantik, merajut, mengelas dan keterampilan lainnya), bahasa daerah dan budaya daerah, bahasa Jerman dan bahasa Inggris. Penentuannya dikaitkan dengan ketersediaan tenaga pengajar, buku pelajaran dan sumber belajar lainnya serta sarana yang diperlukan dalam pelaksanaan kurikulum tersebut. Isinya ditentukan oleh daerah, dalam hal ini Kantor Wilayah Departemen Agama setelah mendapat informasi, saran dan masukan dari Pemerintah Daerah, para tokoh masyarakat dan insatansi terkait, baik tingkat provinsi maupun tingkat kabupaten pada wilayah provinsi.

Program Keterampilan yang dikembangkan oleh MAN I Samarinda erat kaitannya dengan kondisi kota Samarinda pada khususnya, dimana Sektor industri merupakan salah satu sektor yang ikut berperan dalam pembangunan Kota Samarinda. Sebagai suatu wilayah dengan status Ibu Kota, maka sektor industri diarahkan menjadi tulang punggung ekonomi Propinsi Kalimantan Timur dan Nasional. Perkembangan Jumlah industri yang ada selama periode tahun 2003 sampai dengan tahun 2007 menunjukkan kondisi perkembangan yang cukup baik, dimana industri yang ada terbagi dalam beberapa jenis industri yaitu: Jenis industri agro, Jenis industri hasil hutan, kimia, pulp dan kertas, Jenis industri elektronik dan aneka, Jenis industri logam, mesin dan perekayasaan. 
Dari data yang ada jumlah industri pada tahun 2007 sebesar 867 unit dengan tenaga kerja sebanyak 7.299 orang. Perkembangan jumlah industri di Kota Samarinda dari tahun 2003 sampai dengan tahun 2007 mengalami peningkatan sebesar 178 unit, dan peningkatan jumlah tenaga kerja sebanyak 2.069 orang. Peningkatan jumlah industri ini tentunya akan mendorong terjadinya peningkatan jumlah tenaga kerja siap pakai.

Secara umum potensi Sumber Daya Alam kota Samarinda yang sudah dimanfatkan maupun yang berpotensi untuk dikembangkan antara lain sektor Pertanian dan Kehutanan, Pertambangan dan Penggalian (Batu Bara, Minyak, Bahan Galian, Pasir kuarsa ,Industri dan Pariwisata. Potensi-potensi ini memerlukan tenaga kerja yang kompoten untuk mendukung perkembangannya.

Sedangkan keterampilan tata busana sebagai salah satu program ketampilan MAN I Samarinda diberikan untuk bekal dasar kepada peserta didik. Tujuannya bukan ingin melahirkan penjahit andal, tetapi sekadar menumbuhkan apresiasi tentang bagaimana belajar berkarya dan mengisi kehidupan. Bila pada gilirannya, dijumpai sejumlah lulusan melanjutkan ke sekolah kejuruan yang mengambil jurusan tata busana, itu adalah hasil dari suatu proses belajar yang telah diperoleh. Keterampilan tata busana pada MAN I Samarinda di berikan melalui teori dan praktek, oleh tenaga pengajar yang terbatas, maka perlu penambahan tenaga pendidik/pengajar lagi, dan terkadang alokasi waktu pengajaran pendek, sehingga tugas yang seharusnya diselesaikan tentunya memerlukan waktu tambahan.

Keterampilan Tata Busana merupakan salah satu program yang dilaksanakan di MAN I Samarinda. Pelaksanaan pembelajaran keterampilan tata busana harus didukung oleh sarana dan prasarana yang cukup memadai seperti peralatan, buku pendukung serta guru bidang studi. inilah kendala yang dihadapi pihak madrasah dalam pelaksanaan keterampilan tata busana adalah tenaga pengajar, demikian halnya pada program ketarmpilan las dan otomotif. Pada awalnya tenaga pendidik pada tiga bidang keterampilan pada MAN I Samarinda terpenuhi dengan mempersiapkan tenaga-tenaga yang kompoten di bidangnya masing-masing, tetapi disebabkan adanya perpindahan dan mutasi bagi guru-guru tersebut programprogram tersebut sempat mengalami kendala pada tahun-tahun sebelumnya.

Dewasa ini ketiga program keterampilan tersebut menjadi andalan MAN I Samarinda dalam mengembangkan kurikulum yang ada, dukungan telah diberikan oleh berbagai pihak termasuk pihak Kawnil Depag Kalimantan Timur. Berbenah dalam segala aspek di lakukan oleh MAN I Samarinda sebagai upaya menuju MAK (Madarasah Aliyah Keterampilan) Samarinda. 


\section{Rosdiana}

Berbagai kendala yang dihadapi oleh pihak madrasah MAN I Samarinda terkait program keterampilan, utamanya yang berkaitan dengan beberapa aspek diantaranya:

Pertama, dari segi ketersediaan guru yang terbatas. Program-program keterampilan yang ada dari segi tenaga pendidik/guru memerlukan tenaga yang kompoten terhadap mata pelajaran program keterampilan, terutama penguasaan terhadap materi teori dan praktek. Keberadaan guru-guru juga merupakan kendala tersendiri, apalagi mata pelajaran ini tidak diuankan dan terbatasnya buku paket serta buku-buku pendukung lainnya.

Kedua, peran pemerintah. Kebijakan-kebijakan yang telah di tetapkan hendaknya dibarengi dengan ketersediaan guru-guru terkait dengan mulok (seperti pada MAN I Samarinda yaitu guru program keterampilan) atau peningkatan pelatihan-pelatihan bagi guru bersangkutan, pengadaan buku-buku paket, atau ketentuan pengaturan bagi guru-guru tersebut dan adanya usaha pengembangan kurikulum terkait program-program keterampilan.

Sementara kegiatan keagamaan yang dilakukan di MAN I Samarinda meliputi kegiatan rutin dan monumental dalam proses pembelajaran kurikuler maupun ekstrakurikuler. Seluruh siswa mendapatkan materi tersebut melalui guru mata pelajaran Alquran hadits, Fiqih, Aqidah akhlak, SKI, dan bahasaArab sesuai jadwal yang dibuat dalam kalender akademik. Kemudian pedekatan saintifik yaitu siswa sebagai individu potensial yang siap menemukan hal-hal baru yang bisa dikembangkan. Semua pendekatan tersebut membangun individu siswa yang "ulul $a l b a b^{\prime \prime}$ yang dilakukan dengan keterpaduan kurikulum yang ada.

\section{PENUTUP}

\section{Kesimpulan}

1. Madrasah Aliyah Negeri 1 Samarinda dalam pelaksanaan pembelajaran untuk mempersiapkan generasi Islam yang berkualitas yang sesuai dengan tuntutan dan kebutuhan masyarakat kota Samarinda khsusnya, menjadi wadah pengembangan program-program keterampilan seperti keterampilan tata busana, las, otomotif, dan komputer di samping itu MAN I Samarinda dalam proses pembelajaran mengintergrasikan ketermuatan unsur-unsur lokal dalam mata pelajaran baik intra kurikuler maupun ekstrakurikuler.

2. Perkembangan sosial dan kondisi kota Samarinda sekarang menuntut berbagai pihak untuk merespon hal tersebut, MAN I Samarinda sebagai lembaga pendidikan agama berusaha merespon tuntutan tersebut yang 
semakin hari semakin cepat berubah, apalagi dikaitkan dengan tuntutan harapan masyarakat akan keberadaan madrasah yang mampu menjadi rujukan memadukan ilmu-ilmu agama dan ilmu-ilmu umum. Kecenderungan masyarakat kota Samarinda memilih madrasah sangat responsif dan cukup baik untuk mempersiapkan peserta didiknya terjun ke pasaran kerja dengan program-program keterampilan yang ada.

\section{Rekomendasi}

1. Perlu pengadaan guru mulok khusunya program-program keterampilan dan pelatihan untuk peningkatan profesional guru serta program pendidikan lanjut, perlu penyediaan buku dan penunjang belajar lainnya yang memadai, Perlu ada kajian ulang terhadap kurikulum muatan lokal yang dilakukan secara bersama stokeholder pendidikan sehingga betul-betul mengenal, memahami, membudayakan serta akrab dengan lingkungan dalam mempelajari nilainilai agama, budaya, pertanian, industri dan potensi alam lainnya.

2. Memenuhi kebutuhan tenaga pendidik yang terkait program yang telah ditetapkan hendaknya dibarengi dengan kebijakan. Kerjasama guru dengan para masyarakat, stakeholders terutama Dewan Pendidikan dan Komite Sekolah/Madrasah perlu di kembangkan dan dimaksimalkan untuk memikirkan dan membicarakan berbagai masalah yang dihadapi dalam penetapan dan pengajaran muatan lokal, hal ini harus diikuti dengan sikap tegas pemerintah, praktisi dan birokrasi pendidikan serta pihak terkait. [*]

\section{Catatan Akhir:}

'Penulis adalah peneliti Balai Penelitian dan Pengembangan Agama Makassar

${ }^{2}$ Lihat Peraturan Pemerintah Republik Indonesia Nomor 55 Tahun 2007 tentang Pendidikan Agama dan Pendidikan Keagamaan.

${ }^{3}$ Malik MTT. 2008. Innovasi Kurikulum Berbasis Lokal di Pondok Pesantren. Balai Penelitian dan Pengembangan Agama: Jakarta.,h. 1

${ }^{4}$ Lihat lebih jauh, Burhan Bungin. 2003. Analisis Data Penelitian Kualitatif. Cet. I. Raja Prasindo Persada: Jakarta.

${ }_{5}^{5}$ Abdullah Idi. 1999. KTSP. Dasar Pemanaman dan Pengembangan. Bumi Aksara: Jakarta., h. 2-4.

${ }^{6}$ H. Oemar Hamalik. 2008. Dasar-DasarPengembangan Kurikulum. Cet. II. PT. RemajaRosdakarya. Jakarta Ji.4. Lihat pula, Wina Sanjay a 2008. Kurikulum dan Pembelajaran, Teori dan Praktek Pengembangan Kurikulum Tingkat Satuan Pendidikan (KTSP). Kencana Perdana Media Group: Jakarta. 
Rosdiana

Departemen Agama. 2003. Undang-Undang Republik Indonesia Nomor 20 Tahun 2003 tentang Sistem Pendidikan Nasional, h. 5

Departemen Agama.2005. BMPM 6 Panduan Pengembangan Kurikulum. Majelis Pertimbangan dan Pemberdayaan Pendidikan Agama dan Keagamaan. Jakarta., h.3.

' Bentuk pelaksanaannya menurut Muslich dalam bentuk kegiatan: pelayanan konseling, pengembangan kreativitas dan kepribadian, melalui ekstra kurikuler, tidak perlu dibuatkan SK, $\mathrm{KD}$, dan silabus, penilaian dilakukan secara kualitatif, difokuskan pada perubahan sikap dan perkembangan perilaku. Lihat Masnur Muslich. 2008. KTSP. Dasar Pemahaman dan Pengembangan. BumiAksara. Jakarta.,h. 17-18.

\section{DAFTAR PUSTAKA}

Bungin, Burhan. 2003. Analisis Data Penelitian Kualitatif. Cet. I. Raja Prasindo Persada. Jakarta.

Departemen Agama R.I. 2003. Undang-Undang Republik Indonesia Nomor 20 Tahun 2003 tentang Sistem Pendidikan Nasional.

.2007. Peraturan Pemerintah Republik Indonesia Nomor 55 Tahun 2007 tentang Pendidikan Agama dan Pendidikan Keagamaan.

2005. BMPM 6 Panduan Pengembangan Kurikulum. Majelis Pertimbangan dan Pemberdayaan Pendidikan Agama dan Keagamaan. Jakarta.

Hamalik, H. Oemar. 2008. Dasar-Dasar Pengembangan Kurikulum. Cet. II. PT. Remaja Rosdakarya. Jakarta.

Idi, Abdullah. 1999. Pengembangan Kurikulum, Teori dan Praktek. Cet. II. Gaya Media Pratama. Jakarta.

Muslich, Masnur. 2008. KTSP. Dasar Pemahaman dan Pengembangan. Bumi Aksara. Jakarta.

Malik MTT A. 2008. Innovasi Kurikulum Berbasis Lokal di Pondok Pesantren. Balai Penelitian dan Pengembangan Agama. Jakarta.

Sanjaya, Wina. 2008. Kurikulum dan Pembelajaran, Teori dan Praktek Pengembangan Kurikulum Tingkat Satuan Pendidikan (KTSP). Kencana Perdana Media Group. Jakarta. 